\title{
固定装置を併用した上下顎部分床義歯の
}

\author{
1 例とその予後観察
}

佐 藤 俊 之* 尾花 甚 - ${ }^{*}$ 井上恵 司 ${ }^{* *}$

\section{A case report for splint denture and its clinical survey}

\author{
Toshiyuki Sato, Jinichi Obana, Keiji Inoue
}

\section{1. 緒 言}

歯牙動摇の原因とされるものには, 外力による脱臼的 骨植破壊, 矯正力, 歯周症, 老人性歯槽骨萎縮, 歯牙・ 頷骨部の手術などあげられている。これら動摇歯に設置 する固定倿置の目的は，すでに弛緩動摇を起している歯 牙をなんらかの方法で結合させ，動摇を防ぎ，咬合に対 する抵抗的固定および咬合力の分散を計り，歯周組織を 保護することである.

この固定装置の具備すべき条件としては, O.Preisse-

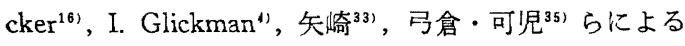
と,できるだけ数多くの方向の圧に対してじゅうぶん固 定すること, 個々の歯牙に働く咬合圧を歯列全体に分配 させること, 画肉に抵触しないこと, 鹳蝕の発生・促進 を来たさず，また万一発生しても完全に処置できるこ と，歯質の削除量を最小限にし，菌髄の失活を必要とし ないこと，審美的に良好であつて，発音・勗嚼障害を最 小限にすること，材質的に耐久力があることとされてい る.

さてこの固定装置を大別すると，着脱性固定装置と非 着脱性固定装置とにわけられる，着脱性固定装置の利点 について O.Preissecker ${ }^{16)}$, K. Greve ${ }^{7)}$, R. Grohs ${ }^{9)}$, A. Elbrecht $^{25}$, K. Koivumaa ${ }^{121}$, 矢崎 ${ }^{31)} ら の$ 意見を引用す

* Dept. of Prosthetic Dentistry, School of Dentistry, Tokyo Medical and Dental Univ. (Chief and Director: Prof. I. Nakazawa)

東京医科歯科大学菌学部補緅学教室 (主任・指導 中沢勇教授)

** Dept. of Dentisttry and Oral Surg., Faculty of Medicine, Kyushu Univ. (Chief: Prof. H. Fujino)

九州大学医学部歯科口腔外科学教室 (主任 藤野博 教授）
ると, 非着脱性固定装置と同じようにじゅうぶんな歯牙 固定をおこなえること，歯牙清掃が可能で口腔内を良好 な衛生状態に保持できること, 万一発生した䠛蝕や必要 な根管治療が容易であること, 生活歯のままで使用でき ること，歯牙の植立方向に左右されないこと，歯牙を同 封に多数失うことなく，また欠損歯は固定装置を破壊す ることなく直ちに補緅できること, 治療時間が短縮でき ること, 製作が容易なこと, 装置の調整・修理が可能で あること，費用が安いことなどとされている，反対に着 脱性固定装置の欠点として O. Preissecker ${ }^{16)}$, M. Si$\mathrm{mring}^{201}$. 矢崎 ${ }^{34}$ らによると，歯牙の固定が強固でないこ と, 装置の変形をおこしやすいこと, 垂直咬合力に対し て抵抗力が少ないこと，審美的に劣ること，患者は精神 的抵抗に打ち克たねばならないことがあげられている.

この着脱性固定装置にも数多くの種類が発表されてい るが, I. Glickman", H. Kazis and A. J. Kazis ${ }^{11}$, F.

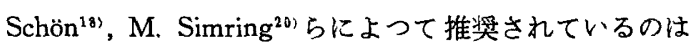
連続鈎による固定装置である。これに属するものには, Case-Sacks ${ }^{34)}$, Rychwalski ${ }^{22)}$, A. Elbrecht ${ }^{3)}$, W. Schalow $^{17)}$, G. Stein ${ }^{221}$, O. Preissecker ${ }^{16)}$, R. Grohs ${ }^{91}$ b による報告があり，本邦でも矢崎 ${ }^{34)}$ ，弓倉・可児 ${ }^{351}$, 中 静・長田ら ${ }^{32}$ によつて針金あるいは鋳造によるものが発 表されている.

われわれは全顎にわたる歯周症で上下顎ともに 2 番か ら 2 番までの宷牙を抜去した症例について，連続鈎を用 い欠損部の補緅と同時に残存歯を固定した部分床義歯を 製作したので, その設計, 装着時の状態および予後を報 告する.

\section{2. 症 例}

初診昭和 36 年 1 月 19 日. 患者は女性 23 葴で上下 


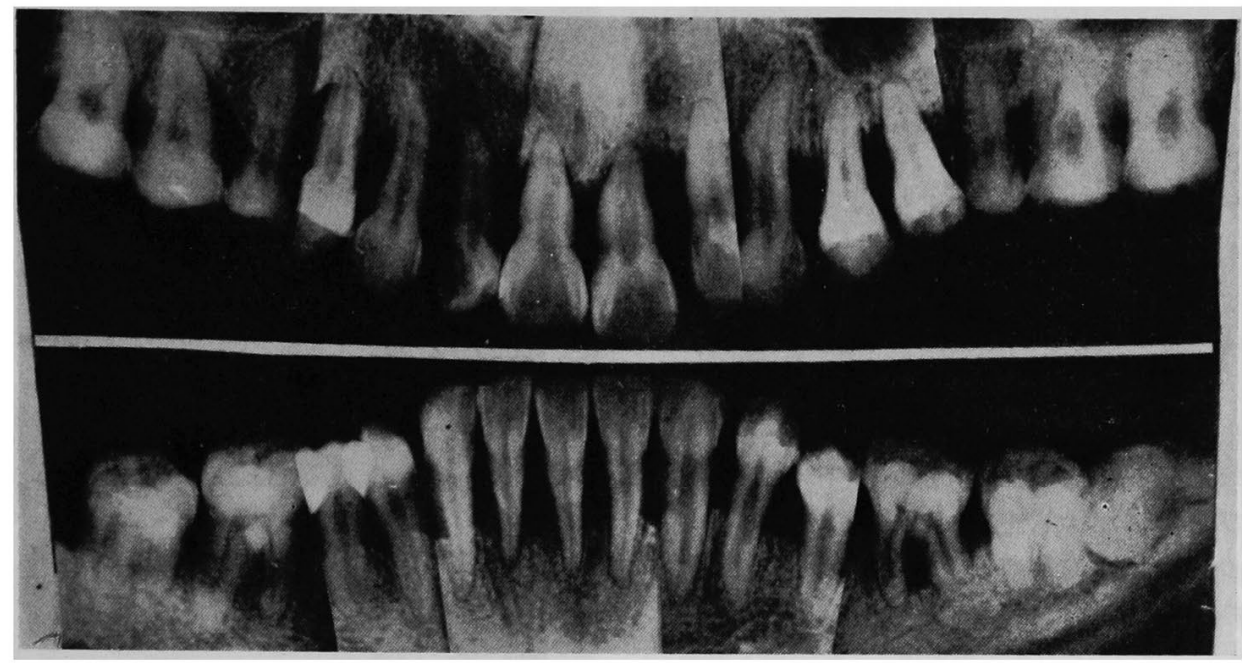

図 1 抜蔽前のレントゲン写真 (35.8.9)

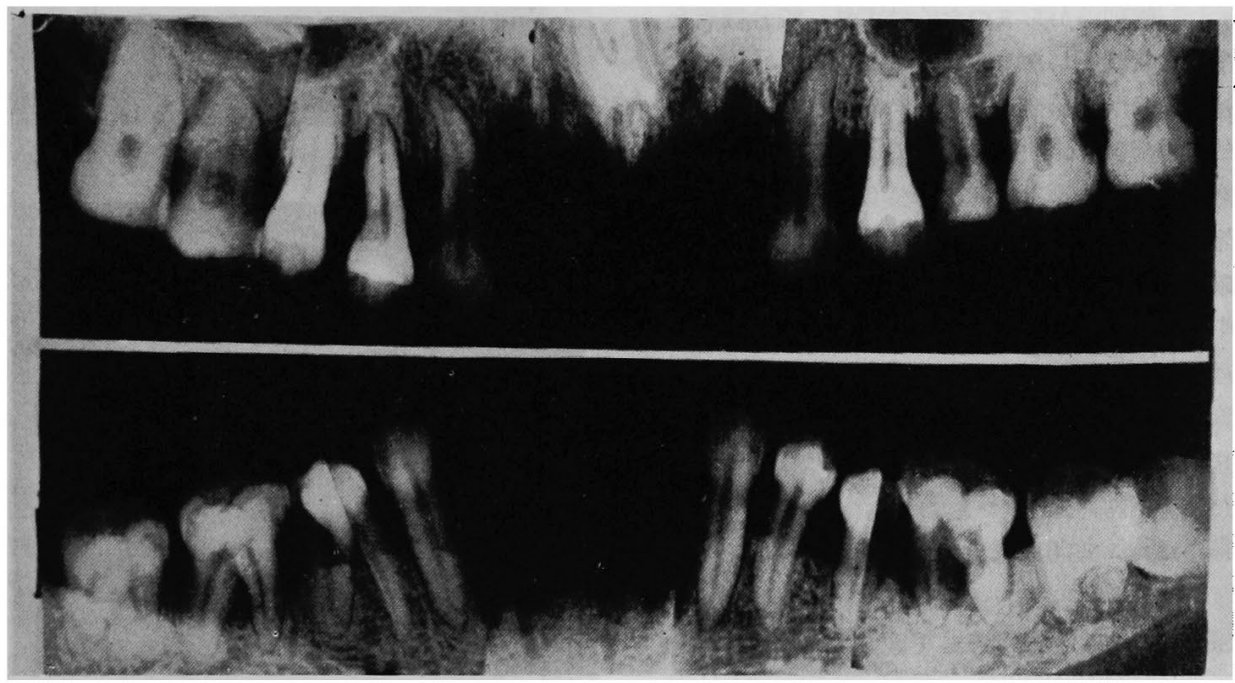

図 2 初猃時のレントグン写真 (36.1.9)

䫑 2 番加ら 2 番までの 義歯再製作を主訴として 来院し た.

既往歴 家族歴および一般的既往歴について特記すべ きことはない，つぎに局所的既往歴についてみると，幼 時から歯牙は健康であつたが, 昭和 27 年頃 (15 歳)から 上下顎前歯部歯肉にわずかの出血と腫脹を認め楽物塗布 を受けた. 昭和 31 年 (19 歳)には歯肉腫脹が上下全狉に 広がり, 昭和 32 年 (20 歳)にはこれに動摇が加わつた. そこで昭和 33 年 8 月 (21 歳) から約半年間, 前半の 3 力 月間は 1 週間 2 回, 後半の 3 力月間は 1 週間 1 回の間隔 で Parotin 注射 (初回 $0.3 \mathrm{mg}$, 次回 $0.6 \mathrm{mg}$ ) を受け症状
は軽減した.しかし昭和 35 年 7 月 (23 歳)には上下前歯 部の動摇, 歯頸部歯肉出血が顕著となり, 上下顎ともに 2 番から 2 番までの抜歯を受け，同時に即時義歯を装着 した. 抜歯前のレントダン写真は図 1 に示した.

現症 体格・栄養ともに良好で顎下リンパ節の明らか な腫脹は認められず，顎関節の状態も正常と思われた. さらに，口腔内所見では欠損歯は上下頻いずれも両側の 中切歯·側切歯であつて, 同部の暫間義歯以外に充填物お

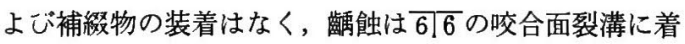
色程度のものがあつた，司は煩側転位をしており，上下 顎両側の大白歯に軽度の咬耗を認めた。口腔粘膜は全䫛 
にわたり歯肉縁部に軽度の発赤があり，歯石沈着はごく わずかで口腔の清掃状態は良好と思われた．な拈歯牙の 弛緩動摇は大部分の歯牙に認められた。 その程度は表 1 に示した.

レントダン診查 図 2 に示したように，全類にわたつ て歯槽骨は水平性の吸収を表わしその程度は高度であ る. すなわち $543 \mid 3$ ，および $543 \mid 345$ 部では歯槽 骨の吸収は菌根の $1 / 2$ あるいは $1 / 2$ 以上であり，特に 4 の 遠心は根尖近くまで吸収像を示している.61456 の菌 槽骨は歯根の $2 / 3$ まで吸収像を認め, 可6では歯根の $1 / 2$ から $2 / 3$ にわたり, 歯根分岐部にも吸収像を示している.

7|ておよび7|7はいずれも正常に近いと思われる。また 歯根膜腔の肥厚は $3 \mid 6$ 亿認められるが，歯根の形態異常 と判断されるものはこのレントダン写真からは見当たら ない.

模型所見 $\overline{76 \mid 67}$ の舌側傾斜が強く, 5|は反対に煩 側転位を示し，歯列弓からまつたくはずれ，晈合機能を 営んでいないと判断された. 4167 ならびに $\overline{64 \mid 6}$ の近 心辺縁隆線部には Clasp を通す閒隙が認められない。

前処置 まず歯石を除去し，次いで司を抜去した．抜 歯創の治瘾後, 研究模型を参考にして口腔を観察し76 煩側咬頭部に早期接触点を認めたので，Wax Bite でそ の位置を確認し，同点と咬合する 76 煩側咬合内斜面を 削除して中心咬合時の咬合平衡を得た．次に連続鈎を走 らせるために, 義歯の着脱方向に対して $\overline{76 \mid 67}$ 舌側豊

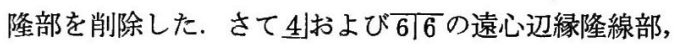

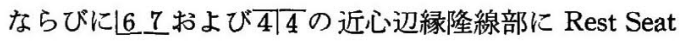
を設定した.

印象採得にはゴム質印象材を使用し，作業模型を製作 した。

設計 Survey Line を基準として図3のように, 残存 全歯牙の舌側に連続鈎を使用し，煩側に鈎腕を回し大部 分の歯牙に Rest をかけて咬合圧を歯列全体に分配する ようにした. 左右側を Bar で連結し, その辺縁と歯肉 縁との距離を $3 \sim 6 \mathrm{~mm}$ あけて設計し, 歯牙欠損部には Resin に対する網目状の保持装置を設けた.

製作 $\mathrm{Co}-\mathrm{Cr}$ 系合金の One Piece Cast 老用い，歯 牙欠損部には人工歯としてレジン歯を使つた. 図 4 は上 喕完成義歯, 図 5 は下顎完成義歯を示した.

装着時の状態 図 6 , 図 7 , 四 8 の上うに上下顎残存 全歯牙はじゅうぶんに固定することができた，そこで装 着前と同じ咬合まで咬合調整をおこなつた．そして人工 歯排列も患者に満足され，咀嚼機能発音も良好な結果を 得た. その後. 歯牙の自発痛, 咀獣時の疼痛もなく, 毎

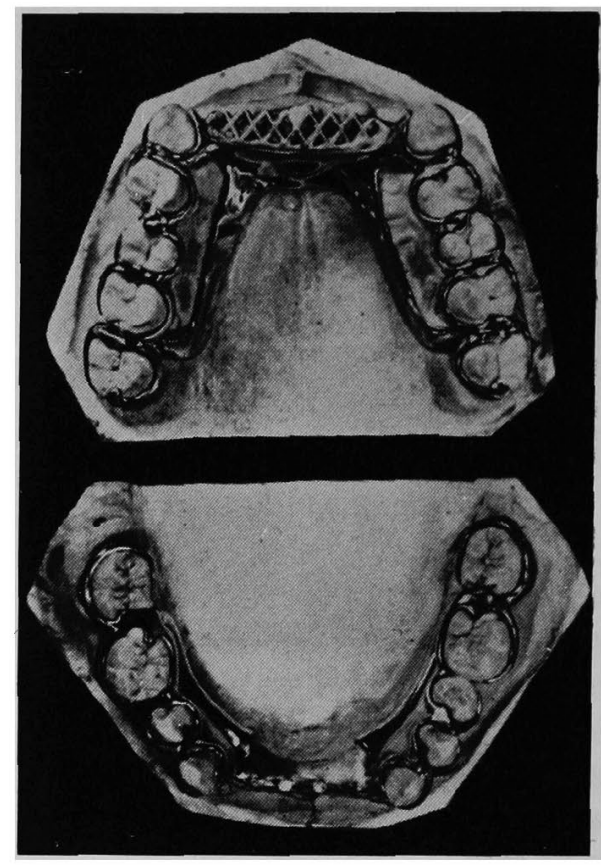

図 3 鋳造完了後模型に試適した上下顎金属床

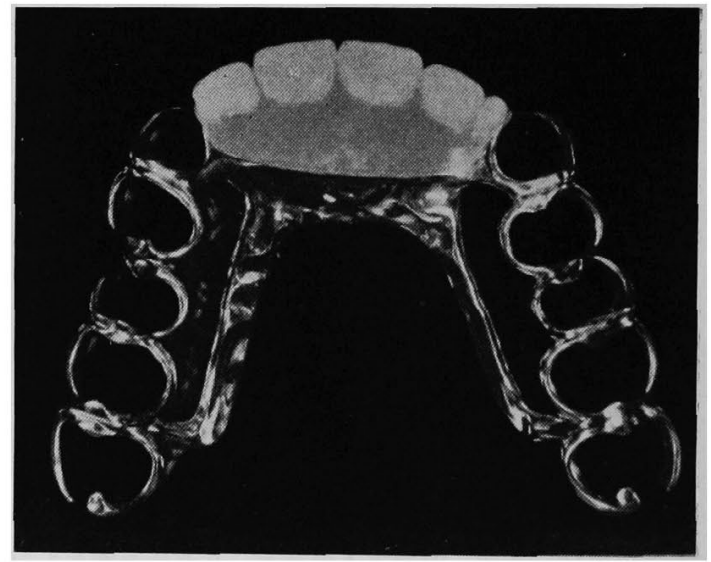

図 4 上顎完成義歯

食後の口腔および義歯清掃を指示するとともに歯刷子マ ッサージを命じた。

\section{3. 予 後 観 察}

本症例の予後観察については, 義歯の適合状態, 䀞

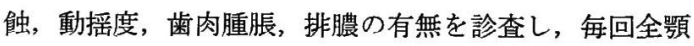
のレントゲン写真を撮影した. 現在までに装着 2 カ月 後, 3 力月後, 4 力月後および 6 力月後の計 4 回の結果 が出たので各項目ごとに括めて記載する.

まず, 義歯の適合状態は装着後 2 カ月で $4-3$ 㛲側鈎 


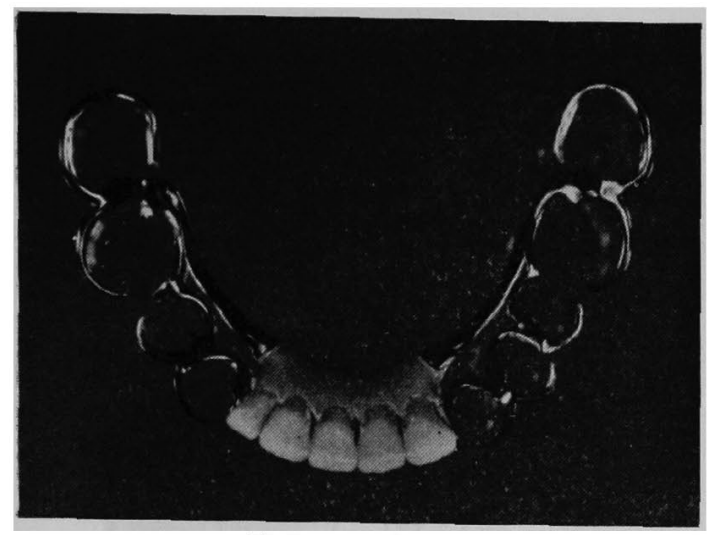

図 5 下顥完成義歯

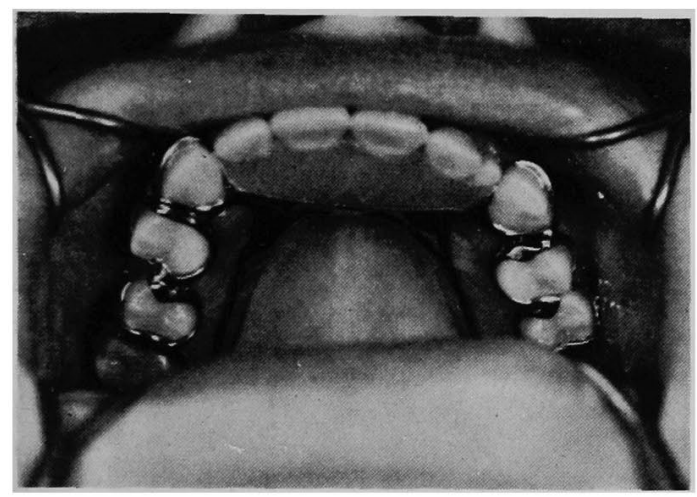

図 6 口腔内に装着した上箩義蒾

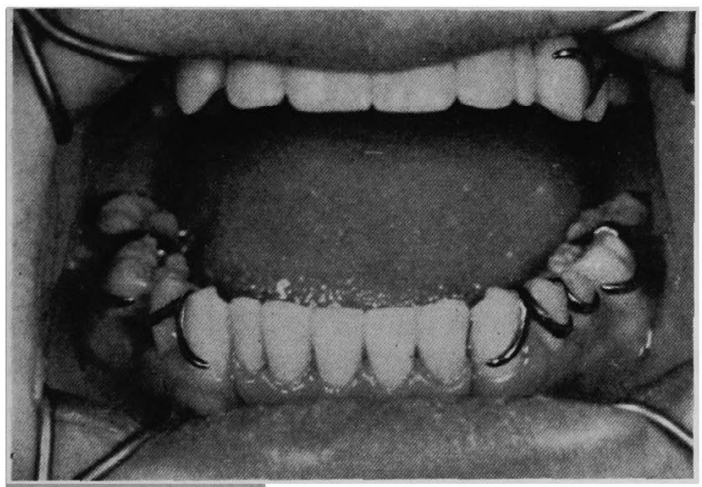

図 7 口腔内に茭着した下䫟義歯

腕にごくわずかの弛みを認めた。これは義歯の着脱時に 誤つた方向人無理に爪をかけるためと推定し, 正しい着 脱方向を指導したのでその後 6 力月まで明瞭な変化は示 さなかつた. 義歯と粘膜々の適合状態は良好であつた. 䠛蝕については特に $\overline{76} / 67$ 舌側豊隆の削除部に発生の 㬓念を抱いて観察したが，6力月後まで肉眼的には発見 されていない，その他の部位にも颣強ならびに Clasp

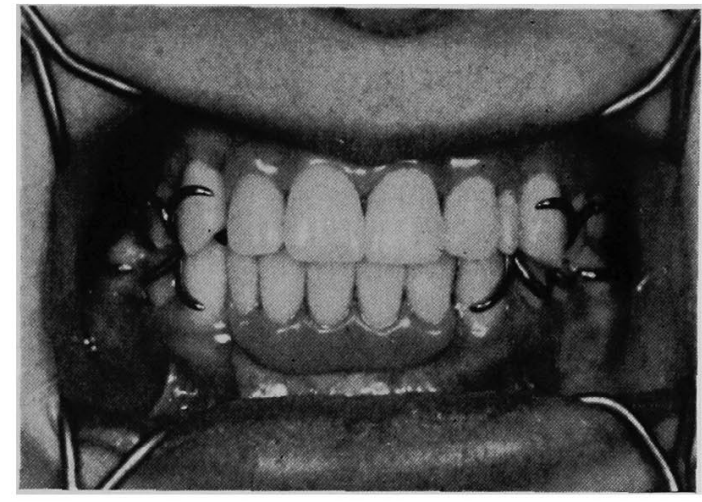

図 8 中心咬合時の上下顎義歯

による摩耗によって起る知覚過敏は認められない。

次に残存歯の動摇度であるが, 診查の方法は動摇度測 定器を用いず, 一般臨床上の 4 度の分類にしたがつて測 定をおこなつた．診査測定にあたつたのは 2 名または 3 名であつて, 部位によつては数值に差異を示したので, 0 度加 I 度，II度から而度という表現を使用した. 表 1 によつて直らに数值比較をすることができないが, 全残 存歯が装着時と比べて悪化していると判断するよりも， 同じ程度かいくらか好転しつつあると推定するのが妥当 と思われる。

さらに歯肉の腫脹についてみると, 装着 2 カ月後, 3 カ月後までは 6 7 7 部の口蓋側歯間乳頭部に 軽度の発赤 腫脹を認めたが, 以後は消失している. 排膿については 義歯装着後 2 力月・ 3 力月までは $\mid 34567$ 部に多少の 排膿をみた. 4 カ月後には同部の排膿は軽度になつた

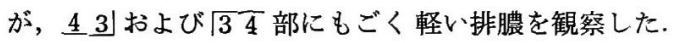
しかし 6 カ月後ではまつたく認められない.

最後にレントゲン診査に関しては, 図 9 の装着 4 カ月 後, 図 10 の装着 6 力月後の写真では骨の新生像は認め られないが，悪化しているとも思われない．

以上，わずか 6 カ月の予後観察では断定はできない が, 臨床所見ならびにレントゲン所見から装着時の病状 を維持しているか, あるいは好転しているとしても，恶 化はしていないと判断される.

\section{4. 考 察}

固定装置として着脱性形式がよいか非着脱性形式がよ

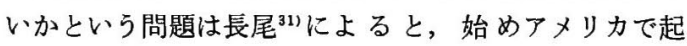
り，後にドイッで激しく論議されたのである。これはち ようどその時代にアメリカで病巣感染説が医学界の焦点 となり，根管治療に対する不信から拔髄を避ける傾向が 歯学界の主流を占めるようになつたためと思われる.こ 
表 1 残 存歯 牙の動摇度

\begin{tabular}{|c|c|c|c|c|c|c|c|c|c|c|c|}
\hline $\begin{array}{l}\text { 予 } \\
\text { 後 }\end{array}$ & $\begin{array}{l}\text { 第 } 4 \text { 回 (6 力月) } \\
\text { 第 } 3 \text { 回 (4 力月) } \\
\text { 第 } 2 \text { 回 ( } 3 \text { 力月) } \\
\text { 第 } 1 \text { 回 ( } 2 \text { 力月) }\end{array}$ & $\left|\begin{array}{c}O \\
O-I \\
\text { I } \\
\text { II }\end{array}\right|$ & $\begin{array}{c}\text { II } \\
\text { I-II } \\
\text { II } \\
\text { I-II }\end{array}$ & $\left|\begin{array}{c}O \\
O \\
O-I \\
O\end{array}\right|$ & $\left|\begin{array}{c}I-I \\
I \\
I-I \\
\text { II }\end{array}\right|$ & $\begin{array}{c}\mathrm{I} \\
\mathrm{O}-\mathrm{I} \\
\mathrm{I}-\mathrm{II} \\
\mathrm{II}-\mathrm{III}\end{array}$ & $\left|\begin{array}{c}O-I \\
\text { II } \\
\text { II } \\
\text { II - III }\end{array}\right|$ & $\mid \begin{array}{c}I-\text { II } \\
\text { I-II } \\
\text { II } \\
\text { II }\end{array}$ & $\mid \begin{array}{c}\text { II } \\
\text { II-III } \\
\text { II -III } \\
\text { III }\end{array}$ & $\begin{array}{l}I-\text { II } \\
\text { I-II } \\
\text { I-II } \\
\text { I-II }\end{array}$ & $\begin{array}{l}0 \\
0 \\
0 \\
0\end{array}$ \\
\hline \multirow[t]{3}{*}{ 装 } & 着 & I & III & I - II & III & $I-I I$ & II - III & $I-I I$ & III - III & II & $O-I$ \\
\hline & & 7 & 6 & 5 & 4 & 4 & 3 & 4 & 5 & 6 & 7 \\
\hline & & 7 & 6 & & 4 & 3 & 3 & 4 & 5 & 6 & 7 \\
\hline
\end{tabular}

\begin{tabular}{|c|c|c|c|c|c|c|c|c|c|c|}
\hline 装 & 着 & $\mathrm{O}$ & I & $\mathrm{O}$ & $O-I$ & $O-I$ & $\mathrm{O}$ & I - II & I - II & $\mathrm{O}$ \\
\hline \multirow[b]{2}{*}{ 予 } & 第 1 回 ( 2 力月) & $\mathrm{O}-\mathrm{I}$ & I & $\mathrm{O}$ & $O-I$ & $\mathrm{O}-\mathrm{I}$ & $\mathrm{O}-\mathrm{I}$ & I - II & I-II & $O-I$ \\
\hline & 第 2 回 ( 3 力月) & $\mathrm{O}-\mathrm{I}$ & I - II & $O-I$ & $\mathrm{O}$ & $O-I$ & 0 & $\mathrm{O}-\mathrm{I}$ & I & $O-I$ \\
\hline \multirow[t]{2}{*}{ 後 } & 第 3 回 (4 力月) & $\mathrm{O}-\mathrm{I}$ & I & $O-I$ & $\mathrm{O}$ & $\mathrm{O}$ & $\mathrm{O}$ & $\mathrm{O}$ & 1 & $\mathrm{O}$ \\
\hline & 第 4 回 (6力月) & 0 & I & $O-I$ & $\mathrm{O}$ & $O-I$ & $\mathrm{O}$ & $\mathrm{O}$ & $O-I$ & I \\
\hline
\end{tabular}

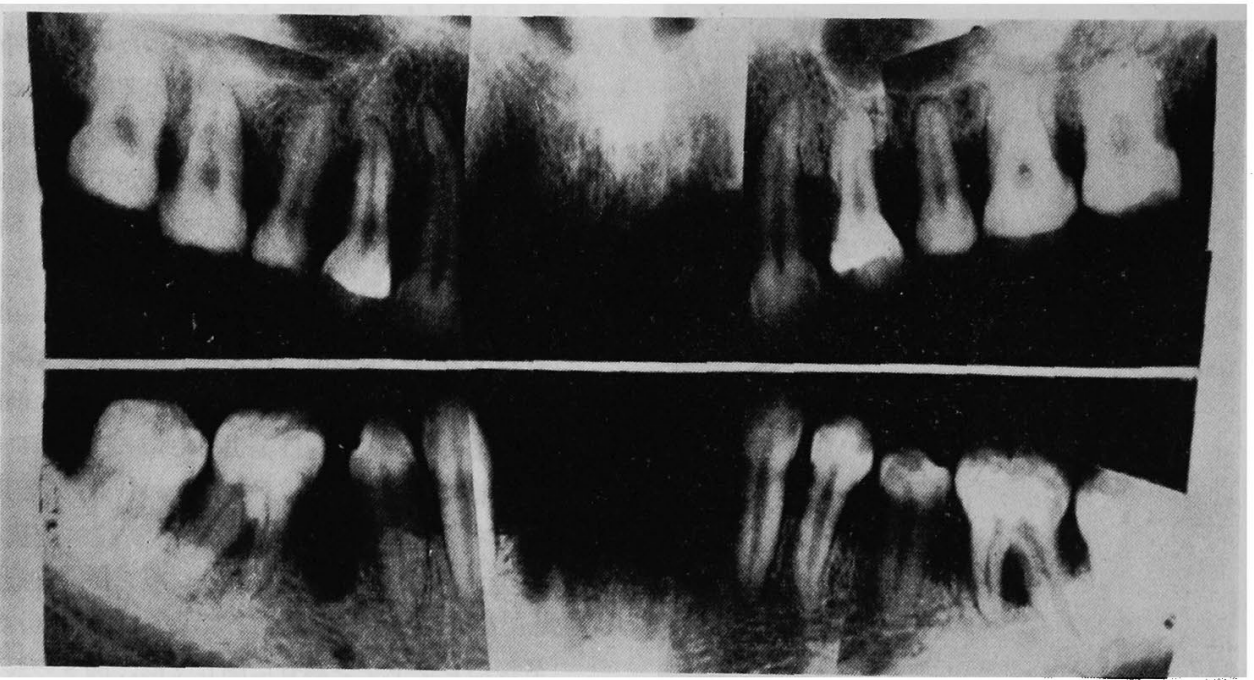

図 9 装着 3 カ月後のレントゲン写真 $(36.6 .17)$

れに伴い従来の固定性橋義歯の優位性が着脱性部分床義 歯人移行する徴候が現われ，当然の結果として固定装置 の分野でも非着脱性固定装置加ら着脱性固定装置人と大 勢が移動を開始したのである.これが 1920 年代から 1930 年代のドイッ歯科界のなりゆきである.

すなわち，緒言で述へたよらに着脱性固定装置の利点 - 久点が詳論され, 非着脱性固定装置に比して着脱性固 定装置の方が優れているとしているのは O. Preissec$\operatorname{ker}^{16)}$, W. Schalow ${ }^{17)}$, R. Grohs ${ }^{91}$, A. Elbrecht ${ }^{31}$, 長

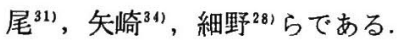

しかし K. Greve" および A. Elbrecht ${ }^{25)}$ らは続いて 1938 年にはこの着脱性固定装置が 良いか非着脱性固定
装置が良いかはその適応症の問題であるという発表をお こない論争に終止符を打つたのである.すなわち,その症 例の歯牙, 歯根膜組織および全口腔器官の関係を慎重に 考慮することが必要であり，歯牙欠損部の大きさと咬合 力の强さも重要なことであると述べている. さらに考慮 すべきこととして，1）䠛蜆素因のある症例では，非着 脱性よりも着脱性固定装置の方が適応症であること，2） 歯周症素因のあるばあいは，レントゲン診査をおこな い，歯槽骨萎縮の種類によつて決定すること，一般に歯 周組織の抵抗力が弱いときには着脱性が選ばれ，強いと きには非着脱性が良いこと，3）病巣感染については， 根尖切除が可能な前歯部は非着脱性でも良いが，臼歯部 


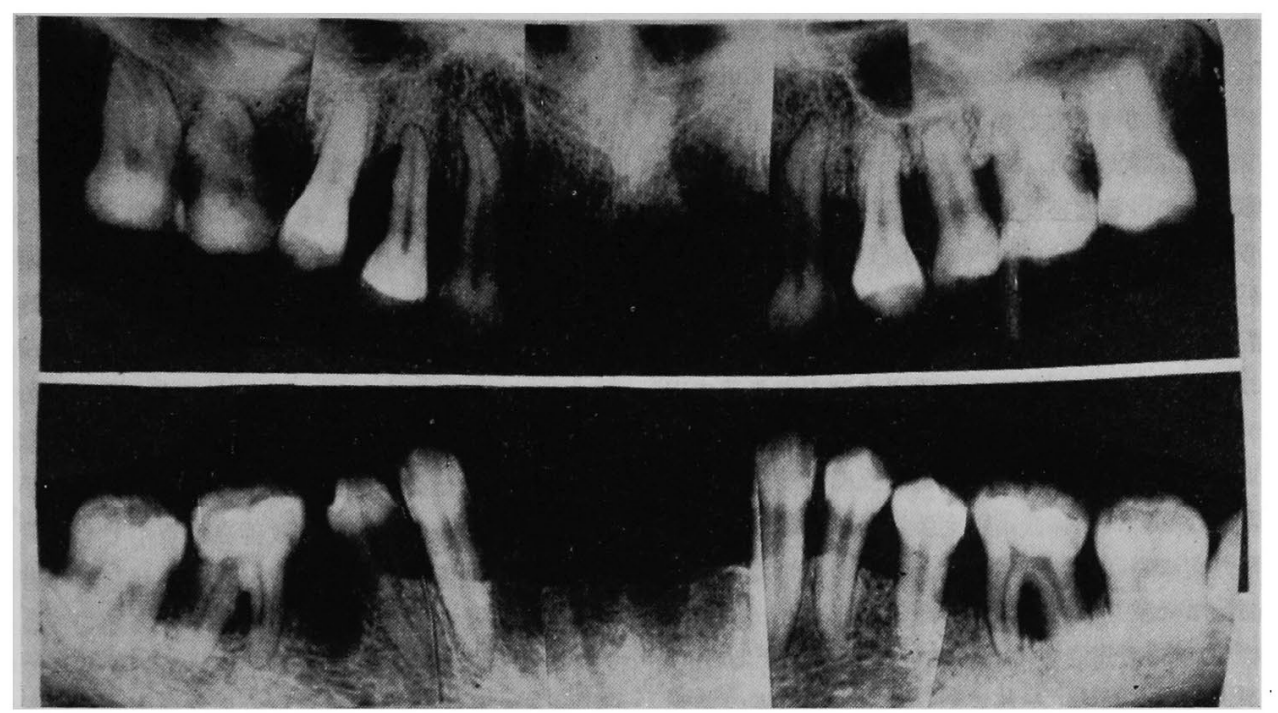

図 10 装着 6 カ月後のレントゲン写真 (36.9.8)

表 2 下顎田歯の煩舌的傾斜角度扣よび捻転角度

\begin{tabular}{|c|c|c|c|c|c|c|c|c|c|}
\hline & 測定值 & 77 & 6 & 5 & $\overline{4}$ & $\sqrt{4}$ & $\sqrt{5}$ & $\sqrt{6}$ & $\sqrt{7}$ \\
\hline $\begin{array}{l}\text { 賽 } \\
\text { 舌 } \\
\text { 的 } \\
\text { 傾 } \\
\text { 符 } \\
\text { 角 } \\
\text { 度 }\end{array}$ & $\begin{array}{l}\text { 実 測 值 } \\
\text { 正常歯列平均值 } \\
\text { 正常 歯列範 囲 }\end{array}$ & $\begin{array}{l}-28.3 \\
-11.76 \\
-19.5 \\
-\tilde{2.5} \\
\end{array}$ & $\begin{array}{l}-22.3 \\
-7.08 \\
-14.5 \\
-\tilde{0.5} \\
\end{array}$ & 梖 & $\begin{array}{c}-6.8 \\
-5.70 \\
-13.0 \\
\tilde{0}\end{array}$ & $\begin{array}{l}-5.5 \\
-5.64 \\
-12.5 \\
\tilde{0}\end{array}$ & $\begin{array}{l}-6.5 \\
-6.72 \\
-17.0 \\
\tilde{0}\end{array}$ & $\begin{array}{l}-19.8 \\
-6.66 \\
-12.5 \\
-\tilde{1.0}\end{array}$ & $\begin{array}{l}-31.2 \\
-12.00 \\
-20.0 \\
-\widetilde{3.0}\end{array}$ \\
\hline $\begin{array}{l}\text { 捻 } \\
\text { 転 } \\
\text { 角 } \\
\text { 度 }\end{array}$ & $\begin{array}{l}\text { 実 測 值 } \\
\text { 正常歯列平均值 } \\
\text { 正常歯列範囲 }\end{array}$ & $\begin{array}{l}81.7 \\
75.24 \\
56.0 \\
\sim \widetilde{85.5}\end{array}$ & $\begin{array}{c}87.2 \\
74.52 \\
55.5 \\
\widetilde{\sim} .0 \\
85.0\end{array}$ & $\begin{array}{l}\text { 位 } \\
\text { 位 } \\
\text { 歯 }\end{array}$ & $\begin{array}{l}43.7 \\
66.48 \\
48.9 \\
\tilde{\sim} \\
83.5\end{array}$ & $\begin{array}{l}43.5 \\
62.16 \\
47.0 \\
\underset{\sim}{\tilde{8} .0}\end{array}$ & $\begin{array}{l}39.2 \\
66.24 \\
28.5 \\
\sim \\
82.5\end{array}$ & $\begin{array}{c}74.1 \\
71.88 \\
60.0 \\
\sim \widetilde{80.5}\end{array}$ & $\begin{array}{l}75.9 \\
73.68 \\
50.0 \\
\widetilde{\sim} .0\end{array}$ \\
\hline
\end{tabular}

は着脱性固定装置にすべきこと，4）残存歯牙の咬合負 担能力の大小によること，5）若年者のばあいは，顎骨 の発育完成期までは着脱性固定装置にすることを主張し ている.

一方，固定装置の適用期間による分類法もある.その 適応症について F. Schön ${ }^{18)}$ の意見によると，暫間固定 装置は 1）外傷あるいは歯牙・頻骨部の手術後の動摇 歯，2）歯周組織治療後の動摇歯，3）結热線に上る転 位歯の矯正治療後の保定，4）永久固定装置の前準供に 使用すべきであるとされる．そして永久固定装置の適応 症は 1）歯周症の歯牙固定，2） 同時に部分床義歯に よる残存歯列の固定，3）特に咬合挙上の目的でおこな ら補緅物による完全な咬合改良法 (Oral Rehabilitation) に用いるべきとしている.なお，期間的にはこれらの中
間に位するものとして, 半永久固定装置を含む分類法 もある. そこで H. L. Ward ${ }^{23}$ は使用される材料や方法 の選択は固定装置を適用する目的とその使用期間に関倸 すると記載している.

結局は中静・長田ら ${ }^{22}$ も指摘しているように, いかな る種類の固定法を採用するか㴹槽骨吸収の程度, 歯牙 の位置, 移動, 咬交歯の歯根の状態, 咬交関係等に左右 され，また矯正的処置や補緅的処置を併用しておこなう 必要上きわめて困難である.

本症例に使用した連続鈎による着脱性固定装置の利点 は固定力がもつとも大きいこと. 製作が比較的容易なこ とである. 連続鈎の作用について W. Schalow ${ }^{177}$ は 1) 転覆防止，2）咬合圧伝達，3）維持力および固定力を あげーている.この作用を効果的にするためには，できる 
だけ多数の歯牙に鈎腕と Rest をつけることは G. Stein $^{22}$, M. Simring ${ }^{201}$, I. Glickman"), H. Kazis and A. J. Kazis ${ }^{11}$ らの衔めるところである.

Rest 設置の意義は M. Simring ${ }^{20)} ら の$ 唱えるように 1 本の歯牙にかかる有害な側方力を根尖方向に変換する ことである.このことについては J. Plitzner ${ }^{15)} の$ 詳細 な研究があり, Rest は蒾軸に平行にかけること，およ び単根歯のばあいは咬合面の中央にかけ，複根歯のばあ いはその1根の中央になるように設置すべきであつて辺 縁部にかけると為害作用があることを記している．また F. Schön ${ }^{18)}$ は個々の歯牙動摇は固定装置によつて完全に は取り除かれないとしても，固定装置全体によって側方 力が歯軸方向に向けられると述べ, これによつて生物学 的に好都合な刺激を歯周組織に与えるだろうという $\mathrm{M}$. Simring ${ }^{201}$ の説に賛意を表している.

本症例では模型所見に記したように下頻大臼歯の舌側 傾斜が顕著である．そこで表 2 に示したように富士川 ${ }^{26)}$ の考案した測定装置を使用して両側大臼歯の煩舌的傾斜 角度と揄転角度とを測定し, 富士川の正常歯列平均值招 よびその範囲を比較した. その結果, 煩舌的傾斜角度に ついてみると，大白歯の測定值はいずれも正常歯列の範 囲外にあり，捻転角度については可が同じく範囲外にあ ることが確かめられたのである。

次に咬合平衡の問題であるが，補緅学においてはそ の意義について幾多の説が 相対立しているところであ $3^{12)}$.

本症例の前処置でおこなつた早期接触点の発見法には 1）咬合紙によつて直接歯牙に部位を印記する方法,

2) H. M. Goldman, S. Schluger and L. Fox ${ }^{5 /} ら の$ Wax Check Bite 法, あるいは I. Glickman")の Wax Template 法, いずれも Base Plate Wax を咬合させて その厚さによつて判定する方法，3）指を唇煩側菌槽骨 に当て咬合時の振動から判定する方法がある. しかし，

1）の方法は動摇歯のばあい咬合時に煩舌的方向への 移動性が大きく，咬合紙が早期接触点以外の部位にも印 記され易いこと，3）の方法は早期接触をする歯牙の鑑 別はつくとしても, その接触点の判定は不確実であるこ とによつて 2) の Wax Bite 法を採用したのである. 咬合平衡を保っために必要なこととして檜垣 ${ }^{277}$ は 1) 全歯牙への均等な圧力分配，2）歯冠および歯根の長さ の良好なる関係，3）歯牙相互間の接触による支持，4） 有害な圧力の加わる咀鲫面の削除をあげている. H.M. Goldman, S. Schluger and L. Fox ${ }^{5)}$ らは歯牙の動摇を 減少させ制限するためと歯牙の生理的形態を確立するた
めに歯牙咬合面の再構成に価值があることを認め，隣接 面とともに煩舌面もこの対象とす心゙きであると記載して いる.

本症例に抒いては前述したように下頻大曰歯部の舌側 豊隆部を削除したが, I. Glickman"1), N. A. Shore ${ }^{19}$ ら も咀唒面積を縮少して咬合圧負担を軽減するために上下 䫟臼歯の煩舌豊隆部の削除を勧めている. 歯周症と咬合 平衡との関係は特に重要であつて，L. G. Jordan ${ }^{10)}$ は次 のよらに主張している.すなわち, 必要なら対額（上顎 に限る）に全部床義歯を装着すると，咬合平衡はとりや すいし，また天然歯よりも咬合力が減少するから残存歯 の歯根膜はいちじるしく改善される. そしてそのさい使 用する人工歯は前歯・臼歯ともにレジン歯の方が良いと し，それはレジン歯のばあいは早く摩耗してより良い咬 合平衡を得ることができるためであると述べている.

さて，本症例では装着 2 力月後で煩側鈎腕にわずかな 驰みを観察した. J. N. Anderson と G. A. Lammie ${ }^{1)}$, J. F. Bates ${ }^{21}$ らの報告によると, Clasp 変形の原因とし てもつとも可能性のあるものは咬合压，義蒾の着脱と 清掃のさいの取り扱い方だとして，特に義歯の着脱時に Clasp の㛲側腕を指でこじ上げることに注意を喚起して いる. L. Nowack and E. Gross ${ }^{13}$ は顕微鏡で義歯床や Bar を観察したところ, 破折の多くは力学的な不均衡に よつておこるものであつて，金属の罪でないことが多い と述べている，連続制を使用するさい汇は，審美性や発 音を損わないように鈎腕を細くする必要に迫まられる。 その上, 連続鈎性全体として長いために外力による変形 が起りやすいので, 変形防止という点でも Restをつけ ることが必要であると中静・長田 ${ }^{322} ら$ は指摘している.

部分床義歯上酮蝕の関倸についてわれわれの調查 ${ }^{301}$ に よると,健全歯を鈎歯として使用したばあい鈎歯の約 30

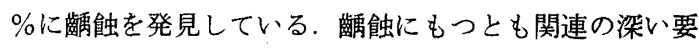
素は, 第 1 に義歯および口腔の清掃不良, 第 2 に就寝時

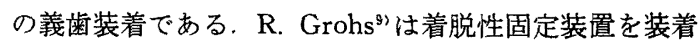
した患者の口腔を観察し少数の症例に舒蝕の 発生を認 め, それらの原因㥙患者の先天的な㻤強素因に加えて就 䕕前に砂糖や粘着力のあるプデイング摄取にあると断 し，朝晚歯牙と固定装置の清掃を徹底的にすることを説 いている、しかし，彼は固定装置を就寝中にも装着すべ きであつて，その方が固定装置本来の目的に適つてい ると述べている.この固定装置を夜間にも装着する問題 は，異常な咬合力を発するとされている歯軋りが歯周症 発生のひとつであり，I. Glickman“は歯軋り防止用の固 定装置を発表していることもあつて，いちがいに固定装 
置の夜間装着を否定することはできないのである，症例 により Caries Activity の程度と歯周症の症状に応して いずれかに決定すべきであると思われる.

歯牙の動摇度を測定することは歯周組織ことに歯槽骨 の病変の程度を推定できるので，歯周症のばあい非常に 重要な診査法である.これにはレントゲン診査だけでな く，臨床的にピンセットで診断する必要があると長尾は 述べているが，その動摇度の表現法について細野 ${ }^{28)}$ は高 度・中等度・軽度とい5分類は不明確なので, 歯牙の静 止位置から移動位置への移動距離を明示すべきであると 記載している．動摇度測定器には歯牙にかける荷重の大 きさ, 歯牙への作用力点としての位置と方向, 装置の固 定の問題があり，前歯部はともかくとして臼歯部は測定 困難なことがある. 本症例における動摇度測定にはピン セットで歯冠をはさみ，いろいろの方向に動かしてみる 方法を使用した．そのさい反対側の人さし指の腹を歯頸 部におき，動摇の伝わり方を触診したＩ度はピンセッ トでわずかに動かすことができる程度であり，II度はは つきり動かすことができ，而度は強く動かすことができ て，IV度は煩舌近遠心方向にも強く動かすことができる だけでなく，歯軸方向にも動かせる程度としている今 川 ${ }^{299}$ の分類にしたがつた. 今川も指摘しているように歯 牙の動摇度は通例歯槽骨の吸収の進行度に比例するもの であるが，必らずしむレントゲン所見と一致するとは限 らないのである.これは歯牙の動摇には歯槽骨以外の組 織の状態が相当強く影響していること，レントゲン写真 像が歯槽骨の病変をそのまま現わすとは限らないことに よるのである. 一般に歯牙の動摇度は炎症が急性化する と強くなり，慢性に移行すると弱くなるものである、そ のさい動摇度の增加は歯肉の炎症症状, 排膿の増加に引 き続いて起るが，減退はそれよりやや遅れて現われる. このように歯牙の 動摇度から歯周組織内部の 罹患状態 をかなり正確に推測することができるので，歯周症の進 行程度, 治療の効果, 予後の判定に重要な参考資料にな るのである.この歯牙の動摇度に関して H.L. Ward ${ }^{23)}$ は次のように記載している.すなわち天然歯は近遠心的 よりもむしろ煩舌的に動摇しやすいが，これは両隣在歯 が相互に近遠心的動摇から起る傷害を防いでいるためで あるとして歯牙接触点の重要性を説いている，そして本 来歯牙の動摇は相対的歯牙動摇と歯槽骨の高さならびに 対合菌列からの力の型と比較することによつて評価され るべきであるとしている．さらに上䫟と下䫟とでは分配 される側方圧が等しくないことを強調しているのは興味 のある問題である.
なお歯牙の動摇は咬合圧以外にも発音・嚥下・呼気・吸 気や唇·煩・舌の運動によつても起るのであり, それぞれ の作用力は咬合力ほど大きくはないとしても，その持続 時間, 回数を乗じて計算するとき決して無視できない因 子であることがわかるのである．このことに関連したも のとして G. J. Parfitt ${ }^{(4)}$ は健全な上䫑中切歯を対象とし て実験をおこない，最大咬合圧では $0.04 \mathrm{~mm}$ の唇側移 動があるのに対し舌の圧迫や嶼下時には $0.02 \mathrm{~mm}$, “th” の発音時には $0.01 \mathrm{~mm}$ の移動があると報告している. また M. S. E. Gould and D. C. A. Picton ${ }^{6)}$ は同じく 唇・煩・舌による歯牙の動摇を測定している.

さて本症例のように下䪽前歯欠損に対して連続鈎を使 用した着脱性固定装置の臨床例を報告しているのは W. Schalow $^{17)}$, A. Elbrecht ${ }^{25)}$, L. G. Jordan ${ }^{10)}$ らである.

A. Elbrecht ${ }^{251}$ はこのような症例は外傷を受けた若年 者に比較的多くみる例であつて, 問題点は欠損歯の両隣 接歯がすでに相当強い動摇を示していることにあると記 載している. また L. G. Jordan ${ }^{10)}$ の報告は 1932 年にあ る保存専問家から 全歯牙の 抜去を要すると診断された 38歳の女性の症例であつて, 上顥に全部床義菌，下顎に は着脱性固定装置を装着したところ22年後の 1955 年, 60 歳のときまで残存歯は全部保存され，歯周症が悪化して いる徵候は少しも認めなかつたと述べている。

なお着脱性固定装置の治療効果に疑問を投しる発表と しては，B. P. Wüst，K. H. Rateitschak および H. R. Mühlemann²)らの論文がある，すなわち彼らは 21 名 の患者を対象とし 1 年から 3 年の間, Mühlemann の動 摇度測定器を使用し, 歯牙動摇度ならびに歯肉の炎症度 の測定を局所治療前と治療後に抗こなつた。そして局所 治療だけを受けた患者群では歯牙の動摇減少が $25.3 \%$ にみられたのに対し，固定装置を装着した患者群では動 摇減少が $11.2 \%$ と約半数であつた.このことから着脱 性固定装置が結局は外傷的に作用するらしいと記述して いる.

いずれにせよ動摇歯の固定装置が歯槽骨の新生を促す ような積極的因子ではない以上，われわれは装着時の歯 牙・歯周組織の状態を悪化させなければ，固定装置の効 果があつたものと考えているのである. もし前記の設計 をしなかつたとすると, 次の可能性が想像される.すな わち，1）より多数歯の抜去を要すること，2）安定が 悪いために義崡の能力が劣ること，3）鈎歯の動摇が早 期におこることである。 


\section{5. 結 論}

われわれは今回全顎にわたる歯周症で上下頡両側の切 歯を抜去した症例について, 残存全歯牙に連続鈎をかけ た固定装置併用の上下顥部分床義歯を製作した。装着後 6 力月までの予後観察によると比較的良好な予後経過を たどりつつあるので固定装置の効果があつたと判断し た.

稿を終るにあたり，終始御㦝篤なる御指導ならびに御 校閲を賜つた中沢教授に深く感謝の意を捧げます.

（な扎本研究要旨は 1961 年（昭和 36 年）第 9 回日本歯 科医学会総会日本補経歯科学会に扣いて発表した).

\section{文献}

1) Anderson, J. N. and l.ammie, G. A. : A clinical survey of partial dentures, Brit. dent. J. 92 : 59-67, 1952.

2) Anderson, J. N. and Bates, J. F. : The cobaltchromium partial denture, Brit. dent. J. 107 : 57-62, 1959.

3) Elbrecht, A. : Systematik der abnehmbaren partiellen Prothese, Leipzig, 1937, Verlag von Hermann Meusser, S. 41-55, 163-169.

4) Glickman, I. : Clinical periodontology, Philadelphia and London, 1955, W. B. Saunders Co., p. 881-928, 964-971.

5) Goldman, H. M., Schluger, S. and Fox, L. : Periodontal therapy, St. Louis, 1956, C. V. Mosby Co., p. 486-498.

6) Gould, M. S. E. and Picton, D. C. A. : A method of measuring forces acting on the teeth from the lips, cheeks and tongue, Brit. dent. J. 112 : 235-242, 1962.

7) Greve, K. : Paradentosebehandlung durch feste oder abnehmbare Schienen ?, Dtch. zahnärztl. Wshr. 41 : 265-268, 1938.

8) Greve, K. : Grundsätzliches über die unterschiedliche Indikation des festen und abnehmbaren Zahnersatzes, Dtch. zahnärztl. Wschr. 41 : 601-606, 1938.

9) Grohs, R. : Die abnehmbare Greiferschiene, Zeitschr. f. Stomat. 35 : 1513-1522, 1937.

10) Jordan, L. G. : Treatment of advanced periodontal disease by prosthodontic procedures, J. Pros. Den. 10 : 908-911, 1961.

11) Kazis, H. and Kazis, A. J. : Complete mouth rehabilitation through crown and bridge prosthodontics, Philadeliphia, 1956, Lea and Febiger, p. 86-88, 387-444.

12) Koivumaa, K. K., Anderson, J. N. and Hede- gård, B. : Some aspects of partial dentures. Internat. dent. J. 9 : 30-40, 1959.

13) Nowack, L. and Gross, E. : Materialfragen der partiellen Prothese, Viertelj. f. Zahnheilk. 48 : 91-119, 1932 .

14) Parfitt, G. J. : Dynamics of a tooth in function, J. Periodont. 32 : 102-107, 1961.

15) Plitzner, J. : Die Klammerauflage in ihrer funktionellen Tätigkeit als Kaudruckübermittler, Dentist. Reform, 42 : 77-83, 1938.

16) Preissecker, O.: Fixe oder abnehmbare Schienen ?, Zeitschr. f. Stmat. 33 : 1409-1423, 1935.

17) Schalow, W. : Die partielle Frothese in Theorie und Praxis, Die fortlaufende Klammer, $\mathrm{Za}$ hnärztl. Rsch. 44 : 1674-1683, 1935.

18) Schön, F.: Die temporäre und definitive Schienung von Zahnen (Fixation, Blockierung, Splintage), Dtch. zahnärztl. Zeitschr. 16 : 634640, 1961.

19) Shore, N. A. : Occlusal equilibration and temporomandibular joint dysfunction, Philadelphia and Montreal, 1959, J. B. Lippincott Co., p. 227-265.

20) Simring, M. : Splinting, theory and practice, J. Amer. dent. Ass. 45 : 402-414, 1952.

21) Simring, M. : Occlusal equilibration of the dentition, J. Amer. dent. Ass. 56 : 643-655, 1958.

22) Stein, G. : Klammergerüstbefestigung der partiellen Prothese (Eine Methode zum besseren Schutz der Klammerzähne gegen Lockerung bei gleieichzeitiger Schienungswirkung), Zeitschr. f. Stomat. 32 : 177-195, 1934.

23) Ward, H. L. : An evaluation of periodontal splinting, J. Amer. dent. Ass. 63 : 48-54, 1961.

24) Wüst, B. P., Rateitschak, K. H. and Mühlemann, H. R. : Der Einfluss der lokalen Parodontalbehandlung auf die Zahnlockerung und den Entzündungsgrad des Zahnfleisches, Helv. Odontol. Acta 4 : 58-61, 1960 cit. Dtch, zahnärztl. Zeitschr. $16: 1034-1035,1961$.

25) Tagung der Arbeitsgemeinschaften für Prothetik and Werkstoffkunde zu Berlin am 11 und 12 Juni 1938, Dtch. zahnärztl. Wschr. 41 : 775-783, 1938.

26）富士川善彥：天然歯列弓に打ける 歯冠傾斜角度 及び捻耺角度，口病誌，25:475-494，昭和 33 ， 1958.

27）檜垣麟三：口腔治療学下巻, 東京, 昭和 27,1952 , 医歯薬出版株式会社, 697, 703 頁.

28）細野来馬：歯冠補経学及架工義歯学, 東京, 昭 和 27, 1952, 歯苑社, 299-312 頁. 
29）令川与曹 : 膿漏処置の実際, 東京, 昭和 35,1960 , 医歯薬出版株式会社，19-22 頁.

30）小林俊三・佐藤俊之・河原俊鎯・松元誠：部分 床義歯の予後に関する臨床的研究, 第 3 報, 鈎 歯の薂蝕について, 補緅誌, $6: 82-90$, 炤和 37 , 1962.

31）長尾優：動摇歯の固定装置に就て, 日本之歯界, $109: 278-279$, 昭和 4, 1929.

32）中静正・長囦保 - 丸島睠 - 武居篤美：連続鈎 $下$
よる歯槽膿嶀の一固定法に就いて，口病誌，24． 182-185，昭和 32，1957.

33）矢崎正方：動搯歯の 固定装置に就て（その1）, 歯科学報, $41: 842-855$, 昭和 $11,1936$.

34）矢崎正方：動摇歯の固定装置に就て（その2）, 歯科学報, $41: 918-929$, 昭和 11， 1936.

35）弓倉繁家・可児一郎：歯槽膿漏の䤼鉤固定装置 に就て，日本之歯界，145：134-142，昭和 7, 1932 . 